\title{
Performance of Semi Adiabatic DI Diesel Engine with Supercharged air using Crude Jatropha Oil
}

\author{
N. Janardhan, R. P. Chowdary
}

\begin{abstract}
Vegetable oils are the only fuels, can be substituted as alternative to overcome the shortage in developing countries. Using non-edible oil like crude jatropha as alternative, waste land can be effectively cultivated and employment can be improved. Experiments were Initiated on semi adiabatic diesel engine with super charging air through the intake manifold using crude jatropha oil with varied injection pressure and varied injection timing to study the performance of the engine. Tests were also conducted using diesel fuel in diesel engine and engine with high grade heat rejection combustion chamber at recommended injection timing at $27^{\circ} \mathrm{bTDC}$ with super charging air using crude jatropha oil. Improvement in performance was found with super charging when comparing with natural aspiration.
\end{abstract}

Keyword: Vegetable oils, fuels, crude jatropha oil, semi adiabatic diesel engine,

\section{INTRODUCTION}

Vegetable Oils are being considered as an important alternative for diesel due their properties are near to diesel fuels. After went through the experimentation of the different researchers it was cited that the performance was poor, high viscosity, low volatility ,combustion chamber deposits ,fuel system deposits. The other major draw backs that they were found decrease in brake power and increased exhaust emissions[1-8]. Fatty acids presence in the increases the exhaust emissions from the engine. Few researchers conducted their experiments on single cylinder, four stroke, water cooled diesel engine with direct injection diesel engine with $3.68 \mathrm{kw}, 1500 \mathrm{rpm}$ and 16:1 compression ratio with varied injection pressure and varied injection timing using vegetable oil. Increased Injector opening pressure by using the nozzle testing device and the injection timing can be varied by inserting the copper shims between fuel pump and the engine body. It was found that decreased thermal efficiency by $10 \%$ and the $56 \%$ emissions increased and $18 \%$ of NOx oxides decreased comparing with diesel operation. Researchers done thier experimentation with vegetable oil at preheated condition to reduce the viscosity to that of diesel at manufacturer recommended injection timing at $27^{\circ} \mathrm{bTDC}[9-10]$.

Revised Manuscript Received on December 20, 2019.

* Correspondence Author

N. Janardhan*, Faculty of Mechanical Engineering Department, Chaitanya Bharati Institute Science and Technology, Gandipate, Hyderabad, 500075, Telangana State, India.

R. P. Chowdary, Faculty of Mechanical Engineering Department, Chaitanya Bharati Institute Science and Technology,Gandipate, Hyderabad,

(C) The Authors. Published by Blue Eyes Intelligence Engineering and Sciences Publication (BEIESP). This is an open access article under the CC BY-NC-ND license (http://creativecommons.org/licenses/by-nc-nd/4.0/) 500075, Telangana State, India.

Increased Brake thermal efficiency to be $3-4 \%$ and decreased exhaust gas by $4-5 \%$ was and decreased particulate matter by $8-9 \%$. Increased injector opening pressure was found to be positive aspect in increasing the brake thermal efficiency. Experiments were conducted with increasing the injector pressure [11-13]. They were reported that performance of the engine marginally improved. Researchers conducted experiment on conventional engine $3.68 \mathrm{kw}$, speed $1500 \mathrm{rpm}$ with varied injection timing [1415]. Brake thermal efficiency increased by 5-6\%, exhaust gas temperature was decreased by $8-10 \%$ and NOx levels increased by $10-14 \%$.Though the vegetable oil properties are comparable that of diesel, due to high viscous and low fugitivity they needs hot combustion chamber called Low Heat Rejection (LHR) combustion chamber or semi adiabatic engine. When combustion takes place with in the engine, heat will be rejected all three possible ways, through the cylinder head, liner and piston. Restricting heat from engine to surroundings by placing insulation becomes hot combustion chamber and also called semi adiabatic combustion chambers. Heat flow will be restricted by coating the thermal barrier layer to cylinder head, named as low grade heat rejection combustion chamber. If the heat flow will be restricted through the liner and through the piston by keeping the 3mm air gap, is named as medium grade combustion chamber. Restricting the heat by coating to the cylinder head and keeping the air gap in the liner, piston is said to be engine with high grade heat rejection combustion chamber. Author has conducted the tests with alternative fuels with engine with different grade combustion chambers. It was came to know that the improvement with vegetable oil operation was quiet good. As the degree of insulation in the combustion chamber increases from low to high causing reduced exhaust gas temperature and increased volumetric efficiency. Author has made an attempt to experiment with turbocharged air and engine with adiabatic combustion chambers using jatropha oil.

\section{METHODOLOGY}

\subsection{Jatropha Oil(Vegetable Oil).}

Jatroha oil is the suitable to replace the diesel fuel. It will be called with different names moglaerand, beghierand, chandsai yoti in india. It will grow very fast and can be useful various purposes. It can grow with normal rain fall and therefore non forest and degraded land can be effectively useful to cultivate the plant. The plant can bear even without water up to one year. The plant bring in starts the third year onwards and will continue to give next 25 years.

Eyes Intelligence Engineering 


\section{Performance of Semi Adiabatic DI Diesel Engine with Supercharged air using Crude Jatropha Oil}

It is easily fertilize by a seed or stem. The oil is possess toxins and non-edible and can be used only as manure. The assets of the oil is given in the table.1.

Table.1 Properties of Test Fuels

\begin{tabular}{|c|c|c|c|c|}
\hline Test Fuel & $\begin{array}{c}\text { Viscosity at } \\
\text { 25oC } \\
\text { (centipoise) }\end{array}$ & $\begin{array}{c}\text { Specific } \\
\text { gravity } \\
\text { at 25o C }\end{array}$ & $\begin{array}{c}\text { Cetan } \\
\text { e } \\
\text { number }\end{array}$ & $\begin{array}{c}\text { Lower } \\
\text { Calorific } \\
\text { value } \\
\text { (kJ/kg) }\end{array}$ \\
\hline Diesel & 12.5 & 0.84 & 55 & 42000 \\
\hline $\begin{array}{c}\text { Jatropha oil } \\
\text { (crude) }\end{array}$ & 125 & 0.90 & 45 & 36000 \\
\hline $\begin{array}{c}\text { ASTM } \\
\text { Standard }\end{array}$ & $\begin{array}{c}\text { ASTM D } \\
445\end{array}$ & $\begin{array}{c}\text { ASTM D } \\
4809\end{array}$ & $\begin{array}{c}\text { ASTM } \\
\text { D 613 }\end{array}$ & $\begin{array}{c}\text { ASTM } \\
\text { D 7314 }\end{array}$ \\
\hline
\end{tabular}

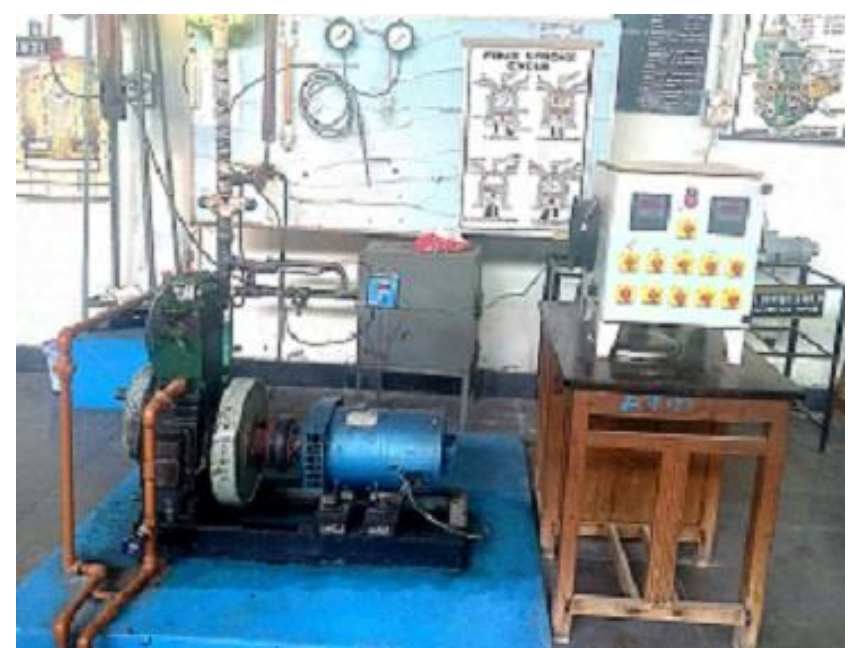

Experimental Setup

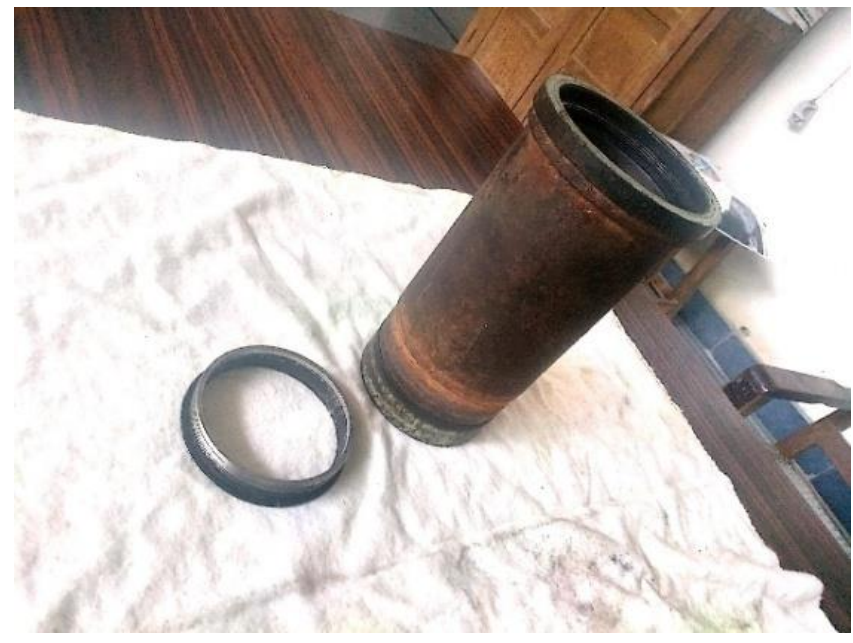

Superni-90 Insert liner

Published By:

Blue Eyes Intelligence Engineering

\& Sciences Publication

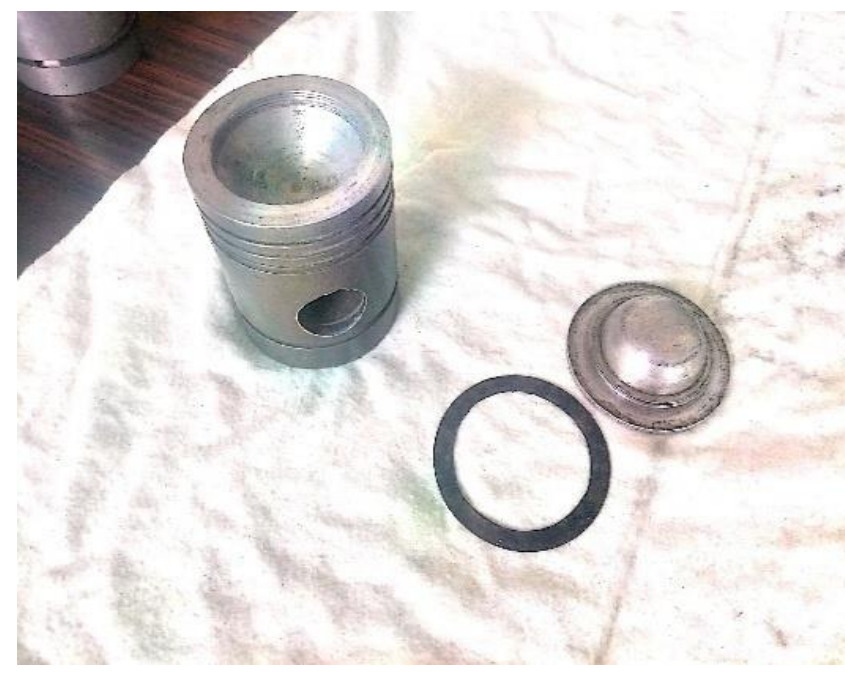

Piston with crown and washer

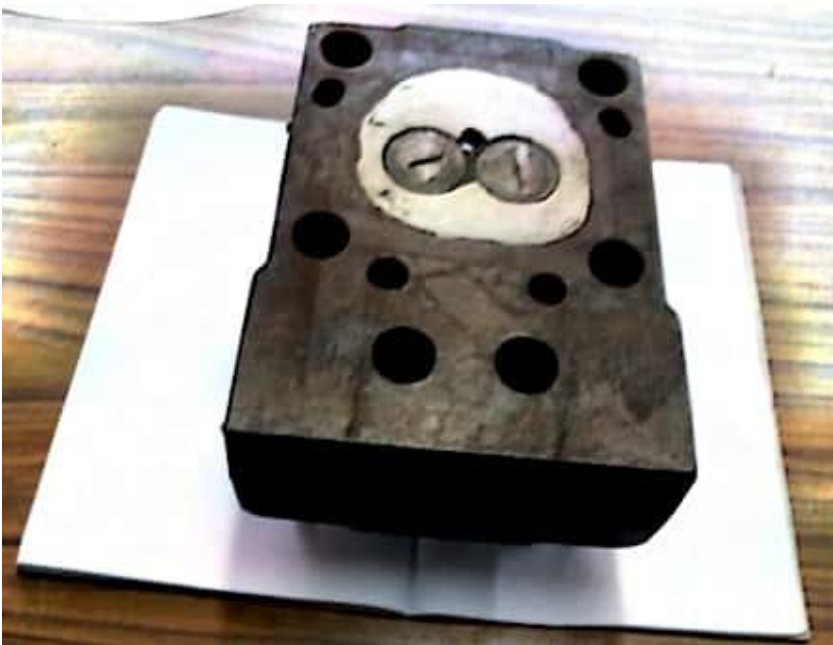

Ceramic coated cylinder head.

Table.2 Specifications of the Test Engine

\begin{tabular}{|l|l|}
\hline Description & Specification \\
\hline Engine make and model & $\begin{array}{l}\text { Kirloskar ( India) } \\
\text { AV1 }\end{array}$ \\
\hline $\begin{array}{l}\text { Maximum power output at a } \\
\text { speed of } 1500 \mathrm{rpm}\end{array}$ & $3.68 \mathrm{~kW}$ \\
\hline $\begin{array}{l}\text { Number of cylinders } \times \text { cylinder } \\
\text { position× stroke }\end{array}$ & $\begin{array}{l}\text { One } \times \text { Vertical } \\
\text { position } \times \text { four- } \\
\text { stroke }\end{array}$ \\
\hline Bore $\times$ stroke & $80 \mathrm{~mm} \times 110 \mathrm{~mm}$ \\
\hline Method of cooling & Water cooled \\
\hline Rated speed ( constant) & 1500 rpm \\
\hline Fuel injection system & $\begin{array}{l}\text { In-line and direct } \\
\text { injection }\end{array}$ \\
\hline Compression ratio & $16: 1$ \\
\hline BMEP @ 1500 rpm & 5.31 bar \\
\hline $\begin{array}{l}\text { Manufacturer's recommended } \\
\text { injection timing and pressure }\end{array}$ & 27 obTDC $\times 190$ bar \\
\hline $\begin{array}{l}\text { Dynamometer } \\
\text { Number of holes of injector } \\
\text { and size }\end{array}$ & $\begin{array}{l}\text { Electrical } \\
\text { dynamometer }\end{array}$ \\
\hline
\end{tabular}

(C) Copyright: All rights reserved.

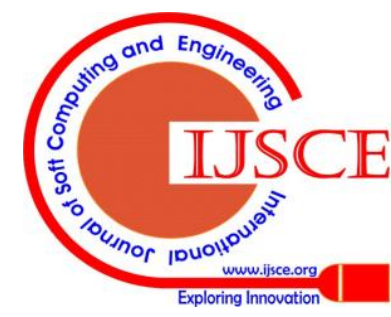


Pressure of 0.8 bar compressed air to the engine manifold from compressed air discharge cylinder and using roto/meter and pressure gauge volume of air and pressure can be measured. The specifications of compressor are shown in Table.3

\section{Table.3 Specifications of the Test Engine}

\begin{tabular}{|l|l|}
\hline Make & Techemshahi, Hyderabad \\
\hline Type & $\begin{array}{l}\text { Reciprocating ompressor } \\
\text { Single Acting }\end{array}$ \\
\hline Bore & $200 \mathrm{~mm}$ \\
\hline Stroke & $300 \mathrm{~mm}$ \\
\hline Pressure ratio & $4: 1$ \\
\hline Volume & $100 \mathrm{cfm}$ \\
\hline Indicated Power & $1 \mathrm{~kW}$ \\
\hline Speed & $300 \mathrm{rpm}$ \\
\hline Clearance factor & $5 \%$ of stroke volume \\
\hline Volumetric Effciency & $90 \%$. \\
\hline
\end{tabular}

e glazed with partially stabilized zirconium with 500 microns by means of plasma arc technique. $3 \mathrm{~mm}$ of air gap can be maintained in the liner by insert which is made up off superni-90 material. A crown is fitted to the piston by means of threaded joint, maintain $3 \mathrm{~mm}$ air gap between the crown surface and the piston surface.

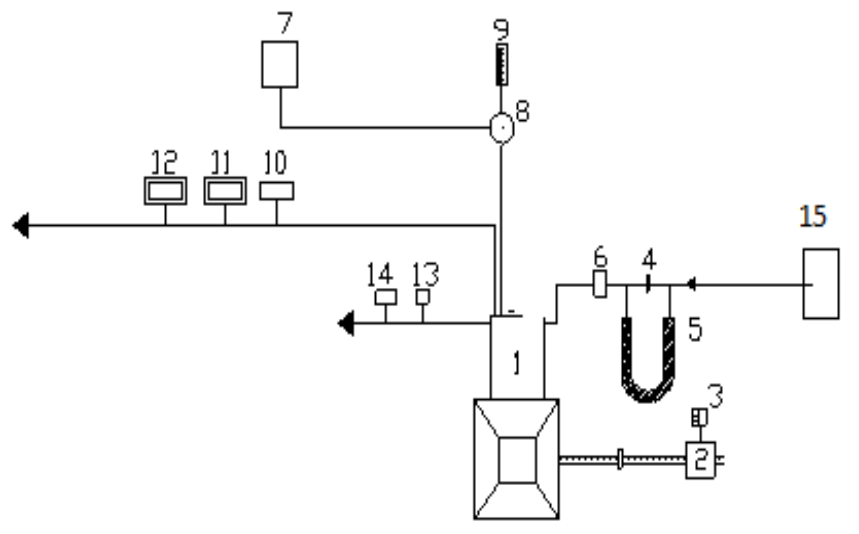

Fig.1 Schematic diagram of experimental set-up

1.Engine, 2.Electical Dynamo meter, 3.Load Box, 4.Orifice meter, 5.U-tube water manometer, 6.Air box, 7.Fuel tank, 8, Three way valve, 9.Burette, 10. Exhaust gas temperature indicator, 11.AVL Smoke meter, 12.Netel Chromatograph NOx Analyzer, 13.Outlet jacket water temperature indicator and 14. Outlet-jacket water flow meter. 15. Positive displacement compressor.

Experiments were borned out with an engine of $3.68 \mathrm{kw}$, $1500 \mathrm{rpm}$ speed with a compression ratio of $16: 1$, direct injection type at manufacturer given injection timing and pressure are $27^{\circ} \mathrm{bTDC}, 190$ bar respectively. The brake power of the engine was measured by means of a dynamometer which is connected to the end of the shaft and the engine was loaded with a rheostat arrangement. Tachometer can be employed for measuring the speed. Fuel consumption can be measured by means of burette. The fuel was injected through conventional injection system. Vegetable oil was pre heated to $90^{\circ} \mathrm{C}$ to equalize the viscosity to that of diesel at room temperature. The intake air of 0.8 bar was given to the engine was measured using pressure gauge. Pressure feed system was used for pumping the engine oil and the changing of the injection pressure was done from 190 to 270 bar with an increment of 40bar using nozzle testing device. The outlet water temperature and exhaust gas temperature was measured with the help of Iron and Iron constantan thermocouple. The accuracy of the thermocouple were taken up to \pm 1 . sound level meter(B \&K type 2238) was used to measure Radiated sound which is coming from the engine at distance of $1 \mathrm{~m}$ from the engine. The sound accuracy levels accuracy were taken \pm 2 decibels.

\section{RESULTS AND DISCUSSIONS}

The performance parameters like brake thermal efficiency, brake specific fuel consumption, exhaust gas temperature, sound levels and volumetric efficiency were studied.

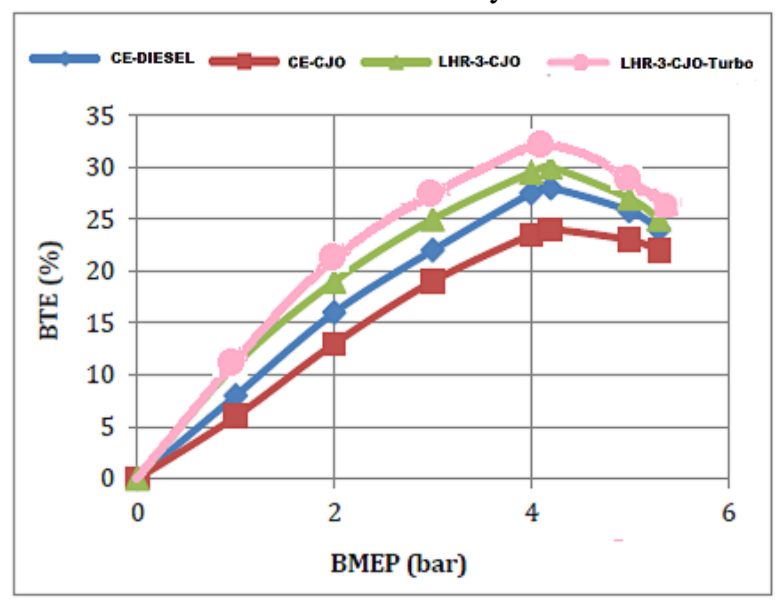

Fig.2 Variation of Brake Thermal Efficiency with Brake mean effective pressure Using diesel, crude jatropha oil in Conventional engine and engine with LHR-3 combustion chamber at recommended injection timing and at 190 bar and with super charging engine with LHR-3 combustion chamber.

Fig.2 shows that the variation of Brake Thermal Efficiency with Brake mean effective pressure Using diesel, crude jatropha oil in Conventional engine and engine with semi adiabatic diesel engine at recommended injection timing and at 190 bar and with super charging engine with LHR-3 combustion chamber. Brake thermal efficiency is increases with increasing brake mean effective pressure at different loads. At $80 \%$ of loads Brake Thermal Efficiency was found to be increased due to the increases the availability of oxygen in the cylinder. Further increasing the load Brake Thermal Efficiency was found to be decreased and Brake Thermal Efficiency decreases in conventional engine with jatropha oil operation due the high viscosity and low calorific value. In case of semi adiabatic diesel engine, variation of Brake thermal efficiency was found to be good improvement. The insulated combustion chamber provides very hot condition in the combustion chamber which makes the fuel to combust successfully as decreasing viscosity and increasing the volatility. In semi adiabatic diesel engine using super charging air with jatropha oil operation, increasing brake thermal efficiency was found to be very good due increase in having the atomized fuel molecules association

Published By:

Blue Eyes Intelligence Engineering

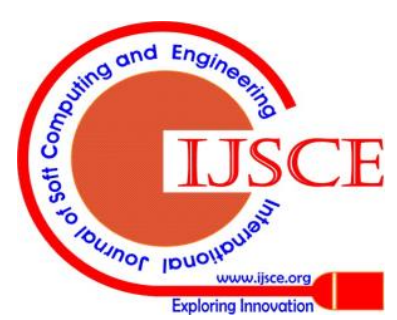


Performance of Semi Adiabatic DI Diesel Engine with Supercharged air using Crude Jatropha Oil

with oxygen molecules to participate in successful combustion.

Table.4 Variation Peak Brake Thermal Efficiency at recommended injection time and Injection Pressure with Turbo charged air

\begin{tabular}{|c|c|c|c|}
\hline & \multirow[b]{4}{*}{$\begin{array}{l}\text { Test } \\
\text { Fuel }\end{array}$} & \multicolumn{2}{|c|}{ Peak BTE (\%) } \\
\hline \multirow{3}{*}{$\begin{array}{l}\text { Timing } \\
\text { ( }{ }^{\circ} \text { bTDC) }\end{array}$} & & \multicolumn{2}{|c|}{ Injection Pressure (Bar) } \\
\hline & & \multicolumn{2}{|c|}{190} \\
\hline & & Conventional & $\begin{array}{c}\text { Turbocharged } \\
\text { air }\end{array}$ \\
\hline \multirow[t]{2}{*}{ 27(CE) } & DF & 28 & 32.2 \\
\hline & $\mathrm{CJO}$ & 24 & 27.12 \\
\hline \multirow[t]{2}{*}{ 27(LHR) } & DF & 27 & 31.59 \\
\hline & CJO & 30 & 35.4 \\
\hline
\end{tabular}

Table.4. shows the brake thermal efficiency at peak load Operation at manufacturer recommended injection timing that is $27^{\circ} \mathrm{bTDC}$ and at recommended injection pressure that is at 190 bar on conventional engine and semi adiabatic diesel engine with and without super charged air .

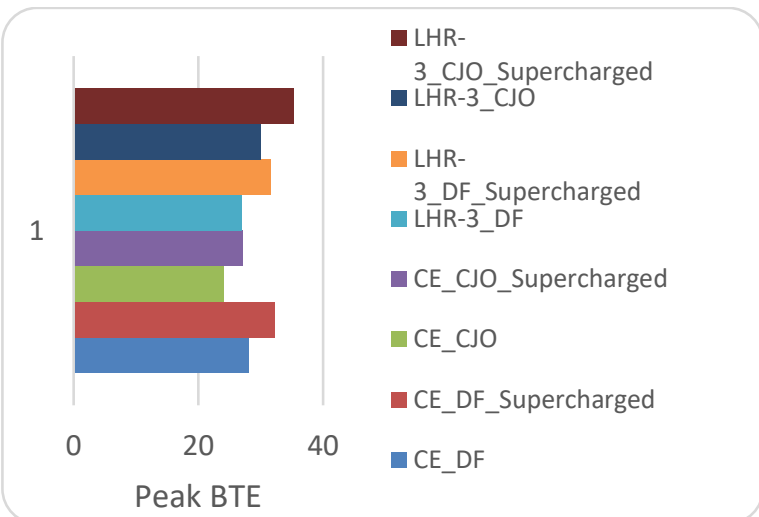

Fig.3. Variation of Peak BTE bar chart with and without super charged air using neat diesel and jatropha oil operation on conventional and semi adiabatic diesel engine.

Fig.3 indicates the peak BTE bar chart at recommended injection time and injection pressure in conventional and semi adiabatic diesel engine. Peak BTE was found to be increased $15 \%$ with supercharged air when compared with without supercharged air and in semi adiabatic diesel of oxygen in the combustion chamber and also due to increase in volumetric efficiency. Due to the increase of additional amount of air, all the fuel molecules successfully burnt and peak pressure was found to be increased. Peak Brake thermal efficiency was found increased $13 \%$ in case of conventional engine with jatropha oil with super charged air over the natural aspiration of the engine. But the percentage of increase when a comparing with conventional engine was found to be less, it is due to high viscosity low calorific value. Brake thermal efficiency in semi adiabatic engine was found to be $18 \%$ over the same version engine with natural aspiration of the engine. Due to very hot combustion chamber make up to burn high viscous crude jatropha oils which will decrease the viscosity and increase the evaporation rate also availability of oxygen and additional pressure of air into the engine, peak pressure was drastically increased. engine, it was found to be $17 \%$. It is due to the availability

Table.5. Variation Peak Brake Specific Energy Consumption at recommended injection time and Injection Pressure with Turbo charged air

\begin{tabular}{|c|l|c|c|}
\hline \multirow{2}{*}{$\begin{array}{c}\text { Injection } \\
\text { Timing } \\
\left({ }^{\circ}\right.\end{array}$} & \multirow{2}{*}{$\begin{array}{c}\text { Test } \\
\text { FTDC) }\end{array}$} & Fuels & \multicolumn{2}{|c|}{$\begin{array}{c}\text { Brake Specific Energy } \\
\text { consumption at full load }\end{array}$} \\
\cline { 3 - 4 } & & \multicolumn{2}{|c|}{190} \\
\hline & & conventional & $\begin{array}{c}\text { Turbo } \\
\text { charged air }\end{array}$ \\
\hline $27(\mathrm{CE})$ & DF & 4 & 3.732 \\
\cline { 2 - 4 } & CJO & 4.96 & 4.58304 \\
\hline 27(LHR) & CE & 4.4 & 4.14128 \\
\cline { 2 - 4 } & CJO & 3.92 & 3.7044 \\
\hline
\end{tabular}

Table 5. Shows the Brake Specific Energy consumption at peak load operation using conventional and semi adiabatic combustion chamber at recommended injection pressure and injection time using neat diesel and jatropha oil operation.

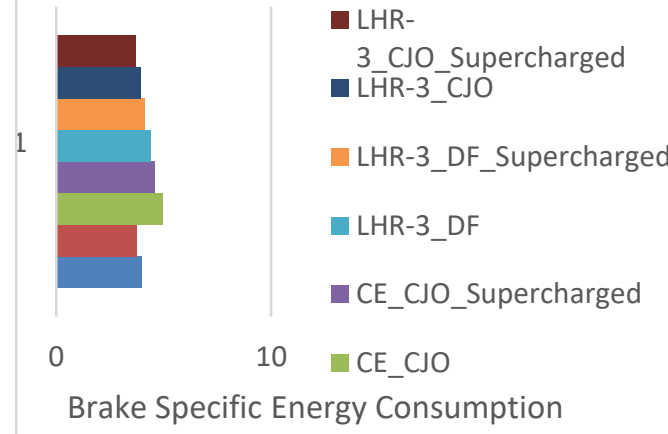

Fig.4. Variation of Brake Specific Energy Consumption bar chart at peak load operation with and without super charged air using neat diesel and jatropha oil operation on conventional and semi adiabatic diesel engine.

The brake specific Energy consumption measure the efficiency of the engine to generate unit power by the unit amount of Heat energy supplied to the engine. BSFC found to be less in semi adiabatic engine with super charged air and is high normal diesel engine with vegetable oil operation. Brake specific energy consumption was found $7 \%$ less when compared with natural suction of air. In case of diesel engine, operation with jatropha oil with turbo charged air, brake specific energy consumption was decreased $8 \%$ when compared with natural suction of air. It was decreased $6 \%$ in semi adiabatic combustion chamber using diesel fuel with turbo charged air when compared with conventional suction of air and with jatropha oil. It was found to be decreased 5\% compared with natural suction with the same version. It was decreased $2 \%$ with semi adiabatic engine with jatropha oil in contrast with conventional engine with neat diesel operation and $7 \%$ decreased with same version engine using jatropha oil with turbocharged air when contrast with diesel fuel in normal engine.

Published By:

Blue Eyes Intelligence Engineering 
Table.6. Variation volumetric efficiency at recommended injection time and Injection Pressure with Turbo

\begin{tabular}{|c|c|c|c|}
\multicolumn{4}{|c|}{ charged air } \\
\hline $\begin{array}{c}\text { Injection } \\
\text { Timing } \\
\left({ }^{\circ}\right.\end{array}$ & $\begin{array}{c}\text { Test } \\
\text { bTDC) }\end{array}$ & \multicolumn{2}{|c|}{$\begin{array}{c}\text { Volumetric efficiency at } \\
\text { full load }\end{array}$} \\
\cline { 3 - 4 } & & \multicolumn{2}{|c|}{190} \\
\hline \multirow{2}{*}{$27(\mathrm{CE})$} & DF & 85 & 102 \\
\cline { 2 - 4 } & CJO & 82 & 98.4 \\
\hline 27(LHR) & CE & 78 & 93.6 \\
\cline { 2 - 4 } & CJO & 79 & 94.8 \\
\hline
\end{tabular}

Table 6. Shows the volumetric efficiency at peak load operation using conventional and semi adiabatic combustion chamber at recommended injection pressure and injection time using neat diesel and jatropha oil operation.

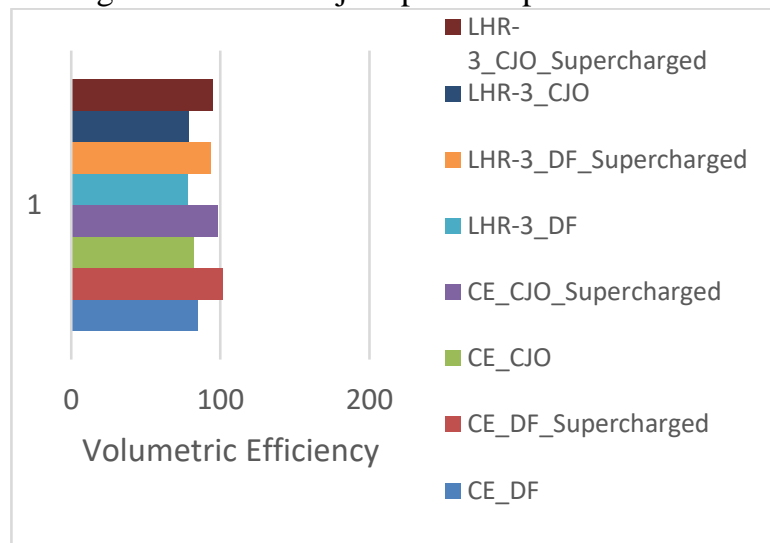

Fig.5. Variation of volumetric Efficiency bar chart at peak load operation with and without super charged air using neat diesel and jatropha oil operation on conventional and semi adiabatic diesel engine.

Volumetric efficiency is proportional to temperature in the cylinder and which in turn depends on density of the fuel. It shows that the increase in volumetric efficiency was found to be $20 \%$ and it is independent of the engine and type fuel that is injected. Volumetric efficiency was found to be more in normal engine with diesel fuel operation. It is because of the conversion of maximum heat into useful work, temperature in the cylinder is low compared to other version of engine, dense of air will enter into the combustion chamber. Volumetric efficiency was increased as the additional super charged air will help to increase the mixing of the fuel particles with oxygen molecules. Volumetric efficiency was very low in semi adiabatic engine with fuel as diesel, due to the degree of hotness in the engine was very high, volumetric efficiency will be decreased. It was be increased by $16 \%$ when compared with conventional engine with normal diesel operation when the operation conventional engine with jatropha oil with turbocharged air. Volumetric efficiency decreased by $7 \%$ in semi adiabatic engine with jatropha oil when compared with conventional fuel with diesel fuel and 12\% increased with semi adiabatic engine with jatropha oil when compared with conventional engine with diesel fuel. Due to supercharged air additional amount of oxygen molecules presence in the cylinder, combustion rate increases, converted into useful thrust force and heat flow through the walls will be decreased. It shows

with semi adiabatic engine with jatropha oil with supercharged air improves the performance.

Table.7.Variation Exhaust Gas Temperature(EGT)at recommended injection time and Injection Pressure with Supercharged charged air

\begin{tabular}{|c|l|c|c|}
\hline $\begin{array}{c}\text { Injection } \\
\text { Timing } \\
\left(\begin{array}{c}{ }^{\circ} \\
\text { bTDC) }\end{array}\right.\end{array}$ & Test & \multicolumn{2}{|c|}{ EGT at full load } \\
\cline { 3 - 4 } & & \multicolumn{2}{|c|}{190} \\
\hline \multirow{2}{*}{$27(\mathrm{CE})$} & DF & Conventional & $\begin{array}{c}\text { Turbo } \\
\text { charged air }\end{array}$ \\
\cline { 2 - 4 } & CJO & 480 & 391 \\
\hline 27(LHR) & CE & 500 & 465.6 \\
\cline { 2 - 4 } & CJO & 460 & 490 \\
\hline
\end{tabular}

.Table 7. Shows the Exhaust Gas Temperature (EGT)at peak load operation using conventional and semi adiabatic combustion chamber at recommended injection pressure and injection time using neat diesel and jatropha oil operation From the table 7. It shows that the exhaust gas temperature, in conventional and semi adiabatic engines was decreased due to the additional amount of air through the supercharging makes combustion rate increases and maximum heat will be converted into useful thrust force.

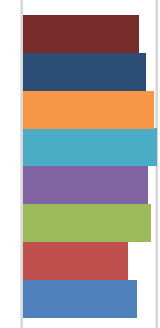

$0 \quad 500$

EGT
- LHR-

3_CJO_Supercharged - L $\mathrm{H}$ R-3_CJO

LHR-

3_DF_Supercharged - L $\mathrm{L}$ R $-\overline{3}$ - DF

- CE_CJO_Supercharged

- CE_CJO

1000 CE_DF_Supercharged

Fig.6. Variation of Exhaust Gas Temperature bar chart at peak load operation with and without super charged air using neat diesel and jatropha oil operation on conventional and semi adiabatic diesel engine.

Exhaust Gas Temperature of the exhaust gasses depends on the heat energy that is being converted into thrust force. EGT was decreased $8 \%$ in conventional engine with turbocharged air when compared with natural sucked air. Due to the availability of excess oxygen molecules in supercharged air, increases the combustion rate and heat converted into useful work. 3\% of heat release is more in conventional engine with jatropha oil when compared with conventional engine with diesel fuel. Due tothe high viscosity of the jatropha oil,fuel will splash onto the cylinder walls, heat release rate takes place after piston reaches the TDC. Therefore, heat loss takes place through the exhaust gas. EGT was found to be decreased 3\% in Conventional engine with jatropha oil with supercharged air when compared with without supercharging but still 9\% more compared with same version with diesel fuel. EGT was decreased $6 \%$ in semi adiabatic diesel engine with jatropha

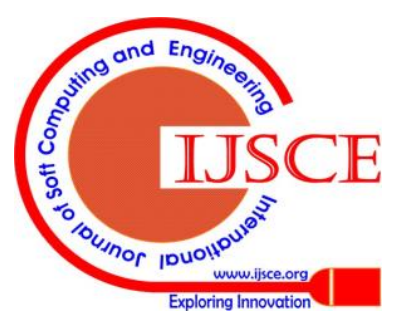


oil with supercharging air when compared with same version engine without supercharging of air but $2 \%$ more when compared with conventional engine with diesel fuel.Though semi adiabatic engine which is a low heat rejection engine to the surroundings, because of the high viscous, heat release rate is slow, part of its heat will be will be carried away by exhaust gasses.

Table.8. Variation Coolant Load (CL) at recommended injection time and Injection Pressure with Turbo charged air

\begin{tabular}{|c|l|c|c|}
\hline \multirow{2}{*}{$\begin{array}{c}\text { Injection } \\
\text { Timing } \\
\left({ }^{\circ} \text { bTDC }\right)\end{array}$} & Test Fuels & \multicolumn{2}{|c|}{ CL at full load } \\
\cline { 3 - 4 } & & \multicolumn{2}{|c|}{190} \\
\hline \multirow{2}{*}{$27(\mathrm{CE})$} & DF & 4 & $\begin{array}{c}\text { Conventional } \\
\text { Tharged } \\
\text { air }\end{array}$ \\
\cline { 2 - 4 } & CJO & 4.3 & 4.128 \\
\hline $27(\mathrm{LHR})$ & CE & 3.4 & 3.332 \\
\cline { 2 - 4 } & CJO & 3.2 & 3.136 \\
\hline
\end{tabular}

Coolant load, which is heat carried away by the coolant were shown in the table. Results are known from the table that coolant load were decreased with the supercharged air.

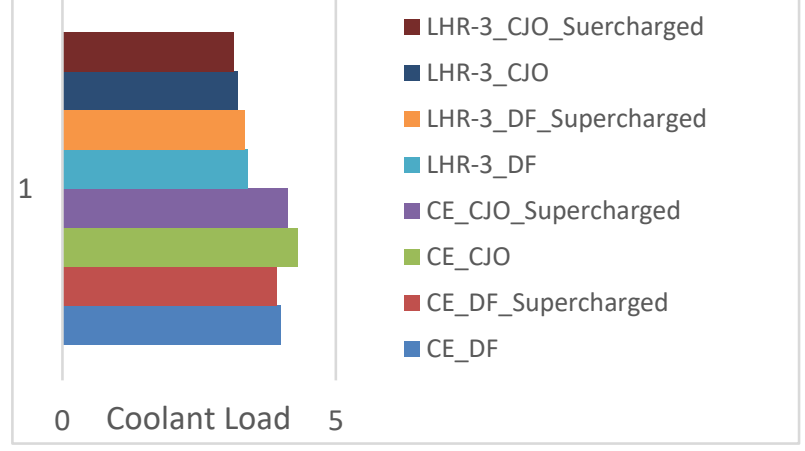

Fig.7. Coolant Load bar chart at peak load operation with and without super charged air using neat diesel and jatropha oil operation on conventional and semi adiabatic diesel engine.

Coolant Load was found to be decreased $2 \%$ in conventional engine with diesel fuel operation with super charged air when compared to same version of engine without super charged. Due to availability of oxygen, conversion of heat into work will be increased. Coolant Load was found to be more in conventional engine with Jatropha oil, due heat release rate is low as it is having more viscosity and $4 \%$ of coolant load was found to be decreased with the same version of engine with supercharging air with jatropha oil. Coolant load was decreased $2 \%$ in engine with semi adiabatic with super charged air with jatropha oil when compared with same version of engine without super charging with jatropha oil and 21\% decreased when compared with conventional engine with diesel fuel without supercharging. Due to heat conversion rate is more into useful work in semi adiabatic diesel engine.

Table.9. Variation Smoke Levels at recommended injection time and Injection Pressure with Turbo charged air.

\begin{tabular}{|c|c|c|}
\hline $\begin{array}{c}\text { Injection } \\
\text { Timing }\end{array}$ & $\begin{array}{c}\text { Test } \\
\text { Fuels }\end{array}$ & $\begin{array}{c}\text { Smoke levels at full } \\
\text { load operation }\end{array}$ \\
\hline
\end{tabular}

\begin{tabular}{|c|l|c|c|}
\cline { 3 - 4 }$\left({ }^{\circ}\right.$ bTDC) & & \multicolumn{2}{|c|}{190} \\
\hline \multirow{2}{*}{$27(\mathrm{CE})$} & DF & 48 & 40.8 \\
\cline { 3 - 4 } & CJO & 65 & 53.3 \\
\hline $27(\mathrm{LHR})$ & CE & 60 & 48 \\
\cline { 3 - 4 } & CJO & 35 & 27.3 \\
\hline
\end{tabular}

Smoke Levels are found to be decreased with the super charging air in both versions of the engine with diesel and jatropha oil.

\section{CONCLUSIONS}

1. The performance of the semi adiabatic DI Diesel engine was found to be improved with crude jatropha oil with super charging at 0.8 bar through intake manifold. Brake Thermal Efficiency was found to be improved $15 \%$ when compared with same version engine when not super charging.

2. Brake Thermal Efficiency was found $13 \%$ improved in engine with conventional engine over the natural aspirated engine.

3. Brake Specific Energy Consumption was reduced $7 \%$ in super charged semi adiabatic diesel engine compared to not having super charging engine.

4. Volumetric Efficiency was found to be improved $20 \%$ in semi adiabatic diesel engine with super charged air when compared with non super charged adiabatic engines.

5. Exhaust Gas Temperature was decreased $8 \%$ in super charged semi adiabatic engine over the same version of engine with no super charging.

6. Coolant load was found to be decreased $2 \%$ in super charged semi adiabatic diesel engine with that of the same version having no super charging.

\section{REFERENCES}

1. Avinash Kumar Agarwal and Atul Dha.(2009), Performance, emission and combustion characteristics of jatropha oil blends in a direct injection CI engine, SAE Paper 2009-01-0947.

2. Misra, R.D, and Murthy, M.S. (2010), Straight vegetable oils usage in a compression ignition engine-A review, Renew Sustain Energy Rev, 14, pp. 3005-3013.

3. Soo-Young, No. (2011), Inedible vegetable oils and their derivatives for alternative diesel fuels in CI engines: A review, Renew Sustain Energy Rev, 15, pp. 131-149.

4. Avinash Kumar Agarwal and Atul Dhar. (2013), Experimental investigations of performance, emission and combustion characteristics of Karanja oil blends fuelled DICI engine, Renewable Energy , 52, pp. 283-291

5. Venkateswara Rao, N., Murali Krishna, M.V.S., and Murthy,P.V.K. (2013), comparative studies on exhaust emissions and combustion characteristics of tobacco seed oil in crude form and biodiesel form in direct injection diesel engine. International Journal of Mechanical and Production Engineering Research and Development, 3(4), pp.25-138.

6. Srikanth, D., Murali Krishna M.V.S., Ushasri, P., et al. (2013), Performance evaluation of a diesel engine fuelled with cotton seed oil in crude form and biodiesel form, Int J Acad Res Multidiscip, 1 (9), pp. 329-349.
Published By:

Blue Eyes Intelligence Engineering

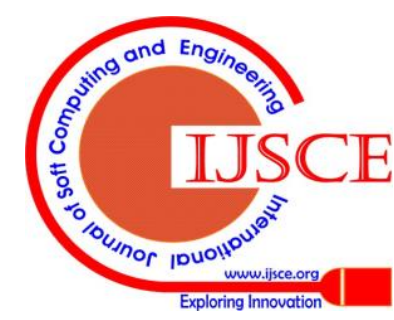


7. Krishna, Maddali., and Chowdary, R. (2014), Comparative studies on performance evaluation of waste fried vegetable oil in crude form and biodiesel form in conventional diesel engine, SAE Paper 2014-011947, 2014.

8. Prasada Rao, D., Murali Krishna., M.V.S., Anjeneya Prasad, B. (2014), Effect of injector opening pressure and injection timing on exhaust emissions and combustion characteristics of rice bran oil in crude form and biodiesel form in direct injection diesel engine, IOSR J Eng 4(2), pp.9-19.

9. Celikten, I. (2003), An experimental investigation of the effect of the injection pressure on the engine performance and exhaust emission in indirect injection diesel engines. Applied Thermal Engineering, 23, pp.2051-2060.

10. Cingur, Y., and Altiparmak, D. (2003), Effect of cetane number and injection pressure on a DI diesel engine performance and emissions. Energy Conversion and Management, 44, pp. 389-397.

11. Hountalas, D.T., Kouremenos, D.A., Binder, K.B., Schwarz, V., \&Mavropoulos, G.C. (2003), Effect of injection pressure on the performance and exhaust emissions of a heavy duty DI diesel engine, SAE Technical Paper No. 2003-01-0340.

12. Warrendale, PA Jindal, S., Nandwana, B.P., Rathore, N.S. and Vashistha,V.. (2010), Experimental investigation of the effect of compression ratio and injector opening pressure in a direct injection diesel engine running on Jatropha methyl ester, Applied Thermal Engineering, 30,442-448.

13. Avinash Kumar Agarwal, Dhananjay Kumar Srivastava, Atul Dhar, et al. (2013), Effect of fuel injection timing and pressure on combustion, emissions and performance characteristics of a single cylinder diesel engine, Fuel, 111, pp. 374-83.

14. Parlak, A., Yasar, H., ldogan O. (2005).The effect of thermal barrier coating on a turbocharged Diesel engine performance and exergy potential of the exhaust gas. Energy Conversion and Management, 46(3), pp.489-499.

15. Ekrem, B., Tahsin, E., Muhammet, C. (2006). Effects of thermal barrier coating on gas emissions and performance of a LHR engine with different injection timings and valve adjustments. Journal of Energy Conversion and Management, 47,pp.1298-1310.

16. Ciniviz, M., Hasimoglu, C., Sahin, F., Salman, M. S. (2008). Impact of thermal barrier coating application on the performance and emissions of a turbocharged diesel engine. Proceedings of The Institution of Mechanical Engineers Part D-Journal Of Automobile Eng,222 (D12), ISSN: : 0954-4070, 2447-2455.

17. Murali Krishna, M.V.S., Janardhan, N., Kesava Reddy,Ch., and Krishna Murthy,P.V. (2014), Experimental investigations on DI diesel engine with different combustion chambers, British Journal of Applied Science \& Technology, 6(3), pp.239-260.

\section{AUTHORS PROFILE}

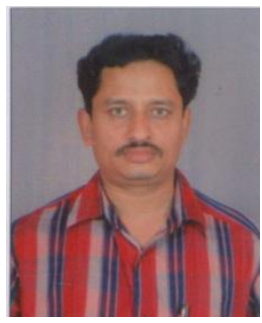

N. Janardhan, Awarded Doctorate from Osmania University, Hyderabad in 2017, Pursuing Research in the area of alternative fuels on semi adiabatic engines. Most of the experiments were carried out on biodiesel and crude jatropha oils. Other area of interest in phase change materials, HVAC. Nearly published 40 International Journals and 5 conferences.

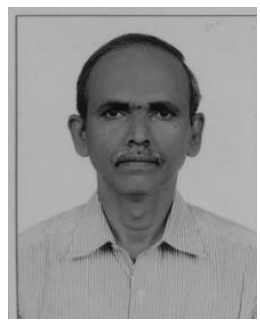

R. P. Chowdary, Awarded Doctorate from JNTU, Hyderabad in Aril 2017, pursuing Research in the area of alternative fuels on LHR engines. Most of the experiments were carried out on biodiesel and waste veritable oils. Area of Interest in Heat Exchangers and Heat and Mass Transfer. Nearly published 50 International Journals and 5 conferences. 